\title{
Toxicological and neurobehavioral effects of chlorpyrifos and deltamethrin insecticides in mice
}

\author{
K.A. Mustafa ${ }^{1}$ and B.Kh. Al-Baggou ${ }^{2}$ \\ Department of Physiology, Biochemistry and Pharmacology, College of Veterinary Medicine, University of Mosul, Mosul, \\ Iraq, Email: ${ }^{1}$ khahmedmustafa@yahoo.com, ${ }^{2}$ banankh71@yahoo.com
}

(Received May 21, 2019; Accepted August 31, 2019)

\begin{abstract}
The aim of the present study was to determine the acute toxicity of chlorpyrifos and deltamethrin in mice separately and to study their toxic and neurobehavioral effects. Median Lethal Doses (LD50) of chlorpyrifos and deltamethrin were determined depending on up and down method. The oral LD50 of chlorpyrifos was $193.05 \mathrm{mg} / \mathrm{kg}$ and of deltamethrin was $15.71 \mathrm{mg} / \mathrm{kg}$ in mice. The oral administration of chlorpyrifos $155 \mathrm{mg} / \mathrm{kg}$ and deltamethrin $12.56 \mathrm{mg} / \mathrm{kg}$ represent $80 \%$ of LD50 resulted in acute signs of poisoning that manifested by dyspnea, salivation and lacrimation at $100 \%$, piloerection, straub tail, tremors, convulsions and death at $70 \%$ for chlorpyrifos and $60 \%$ for deltamethrin and writhing reflex at $20 \%$ for chlorpyrifos. Oral administration of chlorpyrifos $310 \mathrm{mg} / \mathrm{kg}$ and deltamethrin $24 \mathrm{mg} / \mathrm{kg}$ increased severity of toxicosis signs as a percentage of piloerection, straub tail, tremors, seizures and death $100 \%$. As well as decrease the onset of tremors, convulsions and death, writhing reflex which appears at $20 \%$ for chlorpyrifos and $10 \%$ for deltamethrin. After three hours of chlorpyrifos and deltamethrin oral administration at doses represent $20 \%$ and $10 \%$ of $\mathrm{LD}_{50}$ there are significantly hypoactivation in open-field activity, significantly increased in the duration of negative geotaxis performance, significantly decreased in head pocking and swimming scores compared to control group. In conclusion we found that deltamethrin was more toxic than chlorpyrifos this is based on the LD50 value. However, the signs of toxicosis and neurobehavioral effects produced by both toxicants were not differential and could not be associated with the toxic level.
\end{abstract}

Keywords: Avian influenza, RRT-PCR, Histopathology, Rapid test, Broilers Available online at http://www.vetmedmosul.com, () 2020, College of Veterinary Medicine, University of Mosul. This is an open access article under the CC BY 4.0 license (http://creativecommons.org/licenses/by/4.0/).

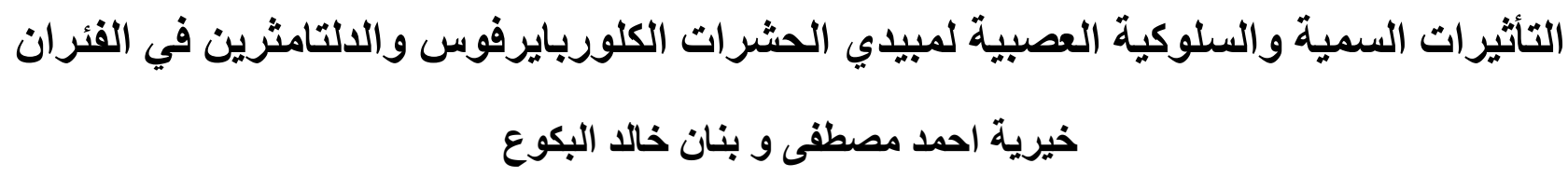

$$
\text { فرع الفسلجة و الكيمياء الحياتية والأدوية، كلية الطب البيطري، جامعة الموصل، الموصل، العراق }
$$

هدف الدر اسة الحالية كان الكثف عن السمية الحادة المحدثة بالكلوربايرفوس و الدلتامثرين كل على حدة في الفئر ان ودر استة تأثئير اتهما

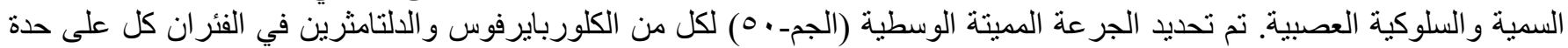

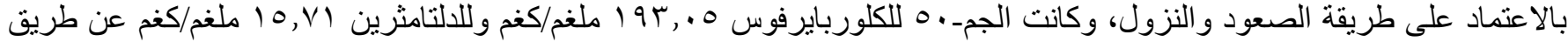

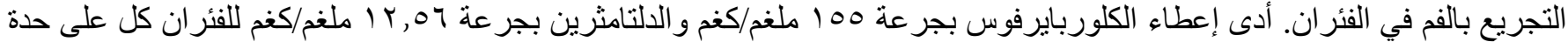

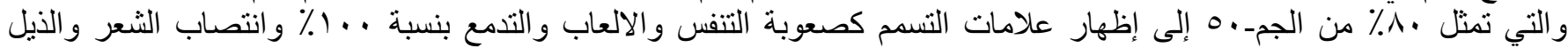

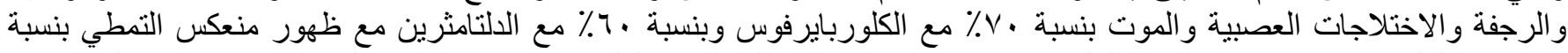

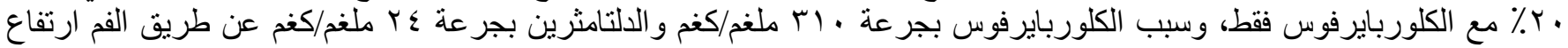

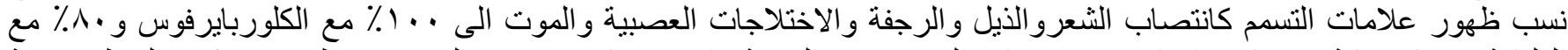

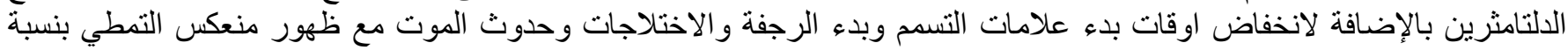




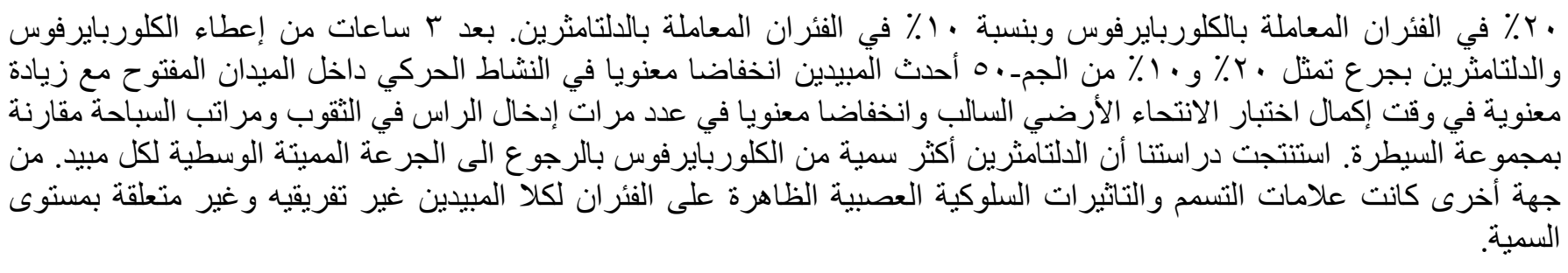

\section{Introduction}

Insecticides known as chemicals manufactured and used to control insects like lice, ticks and used in veterinary medicine to control and eradicate mites and mange $(1,2)$. Chlorpyrifos a broad-spectrum insecticide belongs to organophosphorus compounds. It is used in public health, agricultural crops and in livestock to control different pests $(3,4)$, chlorpyrifos eliminates and eradicates insects by direct exposure or in contact with treated surfaces. Chlorpyrifos classified as a moderate toxic compound within organophosphorus compounds in mice and rats and $\mathrm{LD}_{50}$ ranged between $50-500 \mathrm{mg} / \mathrm{kg}$ body weight (5), as well as have moderate toxicity in sheep and Guinea pigs (3). Toxic effects of chlorpyrifos by affecting normal function of the insect nervous system (6) by irreversible inhibition of acetyl cholinesterase enzyme (AchE) that is responsible for the breakdown of acetylcholine (Ach) (710). After exposure to the toxic doses, signs of poisoning appear within a few minutes or after few hours this depending on the degree of absorption, distribution, metabolism of insecticide inside the body and its excretion (11). Chlorpyrifos poisoning shows the cardinal signs of organophosphorus compounds that is represented by muscarinic signs, which appears early that includes: salivation, lacrimation, sweating, colic with diarrhea, dyspnea with profuse nasal discharges, urination, defecation, miosis and bradycardia $(12,13)$, followed by nicotinic signs that includes: muscle fasciculation, muscle twitching, abnormal gait, in coordination and tremors (14), eventually nervous system effects which includes hyperactivity, anxiety, tremors followed by convulsions, depression and finally death as a result of respiratory failure $(15,16)$. Deltamethrin is a broad-spectrum insecticide classified as type II synthetic pyrethroid (17), pyrethroids are esters analogs of natural pyrithrins (extract of the flower chrysanthemum cineraiaefolium) (18), pyrethroids are used to control and eradicate many pests (19). Deltamethrin has central nervous action and it has cyanide group that linked with sodium channels gaits located in the cellular membrane which lead to produce prolonged inhibition of sodium channels gaits and continuous sodium ions flow so it lowers the action potential threshold and prolonged depolarization resulting in continuous stimulation and hyper activation of the nerve cells $(20,21)$. As deltamethrin classified type II synthetic pyrethroid it shows choreoathetosis with salivation (CS-syndrome) (22). In rodents the appearance of the signs beginning with pawing, burrowing, followed by salivation, dyspnea, in coordination, choreoathetosis followed by seizures and in the late stages there is occurrence of rolling convulsions which are the specific sign of deltamethrin poisoning in rodents and eventually death due to the respiratory failure (23).

Due to the wide disturbing, handling and using of organophosphorus compounds and pyrethroids in veterinary medicine and in agriculture, we select chlorpyriros and deltamethrin that currently used in the markets of Mosul, we aimed in this study was to compare and to study the toxicological and neurobehavioral effects of chlorpyrifos and deltamethrin in mice.

\section{Material and methods}

\section{Animals}

We used 120 white males and females' mice, their ages between 60-90 days, and their body weight between 20-34 $\mathrm{g}$, which housed in the animal house under laboratory conditions 12/12 hours light - dark cycle with water and food ad libitum.

\section{Doses preparation}

A commercial insecticide emulsified solution of chlorpyrifos $48 \%$ concentration (Tarkim, Turkey) and deltamethrin $2.5 \%$ concentration (Indogulf, India), they diluted with distilled water freshly prepared every day before using. The volume of administration was $10 \mathrm{ml} / \mathrm{kg}$ B.Wt. given orally.

\section{Determination of the oral median lethal dose LD50 of chlorpyrifos in mice by up and down method}

Six male and female mice were used and their body weight ranged between 24-34 g, firstly chlorpyrifos dosed orally at $300 \mathrm{mg} / \mathrm{kg}$ depending on previous studies and trails, the result was read death $\mathrm{X}$ or life $\mathrm{O}$ after 24 hour, and the amount of dose increased or decreased was constant $50 \mathrm{mg} / \mathrm{kg}$ and repeat dosing up or down for 3 mice after changing the result death to life and versa and calculate chlorpyrifos $\mathrm{LD}_{50}$ depending upon the diagram and equation of Dixon (24) $\mathrm{LD}_{50}=\mathrm{Xf}+\mathrm{Kd}$, in which Xf: last 
dose, K: diagram value, d: the value of dose increases or decreases.

\section{Determination of the oral median lethal dose $\mathrm{LD}_{50}$ of deltamethrin in mice by up and down method}

Eight male and female mice were used, their body weight ranged between 26-30 g, firstly deltamethrin orally dosed at $30 \mathrm{mg} / \mathrm{kg}$ depending on previous studies and trails, the result was read death $\mathrm{X}$ or life $\mathrm{O}$ after 24 hours, and the amount of dose increased or decreased was constant 5 $\mathrm{mg} / \mathrm{kg}$ and repeat dosing up or down for 3mice after changing result death to life and versa and calculate deltamethrin $\mathrm{LD}_{50}$ depending upon the diagram and equation of Dixon (24) that mentioned previously.

\section{Acute toxic effects of high toxic doses of chlorpyrifos and deltamethrin in mice}

Forty male and female mice were used, their body weight ranged between 22-32 g, groups were orally dosed, directly after oral dosing the mice were observed carefully and acute toxic signs of chlorpyrifos and deltamethrin were recorded during 4 hours, these groups as follows:

Acute toxic effects of $80 \%$ of $\mathrm{LD}_{50}$ of chlorpyrifos and deltamethrin: Twenty mice divided into two groups (10 mice for each group). The first group was orally dosed with chlorpyrifos at $155 \mathrm{mg} / \mathrm{kg}$ B.Wt. While second group was orally dosed with deltamethrin at $12.56 \mathrm{mg} / \mathrm{kg} \mathrm{B}$.Wt.

Acute toxic effects of double doses from A of chlorpyrifos and deltamethrin: Twenty mice divided in to two groups (10 mice for each group). The first group was orally dosed with chlorpyrifos at $310 \mathrm{mg} / \mathrm{kg} \mathrm{B}$.Wt. While second group was orally dosed with deltamethrin at 24 $\mathrm{mg} / \mathrm{kg} \mathrm{B}$.Wt.

\section{Neurobehavioral effects of low doses of chlorpyrifos and deltamethrin in mice}

Sixty male and female mice were used, their body weight ranged between 20-29 g, groups were orally dosed and divided as follows:

Neurobehavioral effects of $20 \%$ of $\mathrm{LD}_{50}$ of chlorpyrifos and deltamethrin: Thirty mice divided in to 3 groups (10 mice for each group). The first group (control) was orally dosed with distilled water. The second group was orally dosed with chlorpyrifos at $38.6 \mathrm{mg} / \mathrm{kg}$ B.Wt. The third group was orally dosed with deltamethrin $3.14 \mathrm{mg} / \mathrm{kg} \mathrm{B}$.Wt.

Neurobehavioral effects of $10 \%$ of $\mathrm{LD}_{50}$ of chlorpyrifos and deltamethrin: thirty mice divided in to 3 groups (10 mice for each group). The first group (control) was orally dosed with distilled water. The second group orally dosed with chlorpyrifos at $19.3 \mathrm{mg} / \mathrm{kg} \mathrm{B}$.Wt. The third group orally dosed with deltamethrin $1.57 \mathrm{mg} / \mathrm{kg} \mathrm{B}$.Wt.

After 3 hours of oral administration of chlorpyrifos and deltamethrin, all mice subjected to neurobehavioral tests.
Open- field activity test: This test measures the locomotors behavior, mice were subjected to the open-field activity test by using $35 \times 35 \times 25 \mathrm{~cm}$ box, the arena of the box was divided into 25 equal squares, and each intended mouse to measure placed in the center of arena and account the number of squares crossed in its four legs, number of rearing, fecal boluses and urination pools within 3 minutes (25).

Negative geotaxis: This test measures neuro-motor coordination, vestibular function and the associated integrative motor response to space orientation, this behavior was measured on slope rough wooden surface at angle $45^{\circ}$ by placing each mouse head down position on the center of an inclined surface and the mouse was timed for completing $180^{\circ}$ turn, and maximum time allowed was 60 second (26).

Head pocking: The test used to measure locomotivity curiosity and movement of treated mouse by using a plastic circular surface it's diameter $30 \mathrm{~cm}$ with low edges and 10 $\mathrm{cm}$ height, the circular surface contain 8 holes $2 \mathrm{~cm}$ each, the mouse placed on the surface and account the head pocking in holes for 3 minutes (27).

Swimming test: This test measures treated mouse response to stressful condition which requires coordination of nerve high centers and neuromuscular responses, this test performed by dropping a mouse in a glass aquarium with the water height $30 \mathrm{~cm}$ and $29-30 \mathrm{C}^{\circ}$ temperature for $5-10$ seconds and watching the mouse carefully and scores recorded (28).

\section{Statistical analysis}

The parametric results were statistically analyzed by using one-way analysis of variance (ANOVA) test version 16.0 , then subjected to least significant difference test depending on statistical analysis program SPSS (29). Were the non parametric results statistically analyzed by using fisher exact test and mann whitny $U$ test, and the level of significance was $\mathrm{P}<0.05(30)$.

\section{Results}

Determination of the oral LD $_{50}$ of chlorpyrifos in mice by up and down method

The oral $\mathrm{LD}_{50}$ of chlorpyrifos was $193.05 \mathrm{mg} / \mathrm{kg}$ body weight after giving different doses with appearance of toxic signs represented by excitation, salivation, lacrimation, defecation, urination, dyspnea, tremors, muscle fasciculation, convulsions, straub tail, piloerection, also writhing reflex in some treatments and eventually death at high toxic doses (Table 1). 
Determination of the oral median lethal dose $\mathrm{LD}_{50}$ of deltamethrin in mice by up and down method

The oral $\mathrm{LD}_{50}$ of deltamethrin was $15.71 \mathrm{mg} / \mathrm{kg}$ body weight with appearance of the toxic signs which represented by excitation, choreoathetosis with salivation, lacrimation, defecation, urination, dyspnea, tremors, muscle fasciculation, rolling convulsions, straub tail, piloerection, also writhing reflex in some treatments and eventually death at high toxic dose (Table 2).

Table 1: Chlorpyrifos $\mathrm{LD}_{50}$ and toxic signs in mice

\begin{tabular}{ll}
\hline Measurements & Result \\
\hline Chlorpyrifos LD $\mathrm{L}_{50}$ & $193.05 \mathrm{mg} / \mathrm{kg}$ orally \\
Doses range & $300-150=150 \mathrm{mg} / \mathrm{kg}$ \\
First dose & $300 \mathrm{mg} / \mathrm{kg}$ \\
Last dose & $150 \mathrm{mg} / \mathrm{kg}$ \\
Up and down dose & $50 \mathrm{mg} / \mathrm{kg}$ \\
No. of mice & $6(X X O X X O)$ \\
Onset of toxic signs & $5-23$ minutes \\
Toxic signs & $\begin{array}{l}\text { Excitation, salivation, dyspnea, } \\
\text { tremors, muscle fasciculation, } \\
\end{array}$ \\
& convulsions, death \\
\hline
\end{tabular}

O: mouse still life during 24 hours, $\mathrm{X}$ : mouse dead during 24 hours.

Table 2: Deltamethrin $\mathrm{LD}_{50}$ and toxic signs in mice

\begin{tabular}{ll}
\hline Measurements & Result \\
\hline Deltamethrin $\mathrm{LD}_{50}$ & $15.71 \mathrm{mg} / \mathrm{kg}$, orally \\
Doses range & $30-10=20 \mathrm{mg} / \mathrm{kg}$ \\
First dose & $30 \mathrm{mg} / \mathrm{kg}$ \\
Last dose & $15 \mathrm{mg} / \mathrm{kg}$ \\
Up and down dose & $5 \mathrm{mg} / \mathrm{kg}$ \\
No. of mice & $8(\mathrm{XXXXOOXO})$ \\
Onset of toxic signs & $5-18$ minutes \\
Toxic signs & $\begin{array}{l}\text { Excitation, choreoathetosis, } \\
\text { tremors, salivation, rolling } \\
\end{array}$ \\
& convulsions, death \\
\hline
\end{tabular}

O: mouse still life during 24 hours, $\mathrm{X}$ : mouse dead during 24 hours.

Acute toxic effects of high toxic doses of chlorpyrifos and deltamethrin in mice

Acute toxic effects of $80 \%$ of $L_{50}$ of chlorpyrifos and deltamethrin

Oral administration of chlorpyrifos at dose $155 \mathrm{mg} / \mathrm{kg}$ B.Wt. and deltamethrin at dose $12.56 \mathrm{mg} / \mathrm{kg} \mathrm{B}$.Wt, in mice led to appearance the signs of poisoning that includes: dyspnea, salivation, lacrimation, which appears in both treatments at $100 \%$, also piloerection, straub tail, tremors, convulsions and death appears in chlorpyrifos treatment at a percentage that more than in the deltamethrin treatment, as well as there is significant increase in the onset of signs time, onset of convulsions time and in death time with chlorpyrifos in comparison with deltamethrin, and increase in the onset of tremors time with chlorpyrifos in comparison with deltamethrin, and writhing reflex appears in some chlorpyrifos treatments at $20 \%$ (Table 3).

\section{Acute toxic effects of double doses from $A$ of chlorpyrifos and deltamethrin}

The oral administration of chlorpyrifos at dose 310 $\mathrm{mg} / \mathrm{kg} \mathrm{B}$.Wt. and deltamethrin at dose $24 \mathrm{mg} / \mathrm{kg}$ B.Wt., in mice led to appearance of the signs of poisoning including: dyspnea, salivation, lacrimation, that appears in both treatments at $100 \%$, also piloerection, straub tail, tremors, convulsions and death appears in chlorpyrifos treatment at percentage more than deltamethrin treatment, also there is increase in the onset of signs time and the onset of tremors time of chlorpyrifos in comparison with deltamethrin, as well as there is significant increase in the onset of convulsions time and in death time with chlorpyrifos in comparison with deltamethrin. Writhing reflex appears in some chlorpyrifos and deltamethrin treatments at $20 \%$ and $10 \%$, respectively (Table 4 ). The double doses of both insecticides that used in this experiment showed an increase in the toxic sign's incidence, intensity and severity.

Table 3: Acute toxic signs induced by chlorpyrifos $155 \mathrm{mg} / \mathrm{kg}$ and deltamethrin $12.56 \mathrm{mg} / \mathrm{kg}$ PO in mice

\begin{tabular}{lcc}
\hline Signs of toxicosis \% & Chlorpyrifos & Deltamethrin \\
\hline Dyspnea & 100 & 100 \\
Salivation & 100 & 100 \\
Lacrimation & 100 & 100 \\
Defecation & 100 & 70 \\
Urination & 100 & 80 \\
Piloerecation & 70 & 60 \\
Straub tail & 70 & 60 \\
Tremors & 70 & 60 \\
Convulsions & 70 & 60 \\
Writhing reflex & 20 & Zero \\
Death & 70 & 60 \\
Onset of signs time & $24.63 \pm 2.16^{*}$ & $19.5 \pm 0.98$ \\
Onset of tremors & $83.1 \pm 1.99$ & $67.75 \pm 4.74$ \\
Onset of convulsions & $91.1 \pm 1.98^{*}$ & $85.13 \pm 4.43$ \\
Onset of death & $149.6 \pm 6.6^{*}$ & $126.88 \pm 5.69$ \\
\hline
\end{tabular}

Values are mean \pm SE for 10 mice / group, * The value significantly different from the group treated with Deltamethrin at $\mathrm{P}<0.05$.

\section{Neurobehavioral effects of low doses of chlorpyrifos and deltamethrin in mice}

This experiment showed that neurobehavioral effects of group A were more pronounced than group B, as well as neurobehavioral effects of chlorpyrifos in group B was more significant than in deltamethrin in the same group. 


\section{Neurobehavioral effects of $20 \%$ of $\mathrm{LD}_{50}$ of chlorpyrifos and deltamethrin}

The oral administration of chlorpyrifos at dose 38.6 $\mathrm{mg} / \mathrm{kg} \mathrm{B.Wt}$ and deltamethrin at dose $3.14 \mathrm{mg} / \mathrm{kg} \mathrm{B} . \mathrm{Wt}$, led to behavioral changes after 3 hours of the treatment which is represented by a significant decrease in the open field activity (squares crossed and rearing) in comparison with the control group, a significant increase in the time spent for the negative geotaxis performance in comparison with the control group, and a significant decrease of head pocking, swimming scores in comparison with the control group, and a significant increase in urination and defecation in comparison with the control group (Table 5).

Table 4: Acute toxic signs induced by chlorpyrifos 310 $\mathrm{mg} / \mathrm{kg}$ and deltamethrin $24 \mathrm{mg} / \mathrm{kg}$ orally, in mice

\begin{tabular}{lcc}
\hline Signs of toxicosis\% & Chlorpyrifos & Deltamethrin \\
\hline Dyspnea & 100 & 100 \\
Salivation & 100 & 100 \\
Lacrimation & 100 & 100 \\
Defecation & 100 & 80 \\
Urination & 100 & 80 \\
Piloerecation & 100 & 80 \\
Straub tail & 100 & 80 \\
Tremors & 100 & 80 \\
Convulsions & 100 & 80 \\
Writhing reflex & 20 & 10 \\
Death & 100 & 80 \\
Onset signs time & $19.1 \pm 1.43$ & $13 . \pm 0.99$ \\
Onset of tremor & $64 \pm 4$ & $55.3 \pm 5.6$ \\
time & & \\
Onset & $76 \pm 5^{*}$ & $64.17 \pm 2.03$ \\
convulsions & $108.3 \pm 2.26^{*}$ & $75.2 \pm 4.75$ \\
Onset of death
\end{tabular}

Values are (mean \pm SE) for 10 mice /group, * The value significantly different from the group treated with deltamethrin at $\mathrm{P}<0.05$.

\section{Neurobehavioral effects of $10 \%$ of $\left(L D_{50}\right)$ of chlorpyrifos and deltamethrin}

The oral administration of chlorpyrifos at dose $19.3 \mathrm{mg} / \mathrm{kg}$ and deltamethrin at dose $1.57 \mathrm{mg} / \mathrm{kg}$ B.Wt., led to behavioral changes after 3 hours of the treatment which is represented by a significant decrease in open-field activity (squares crossed and rearing) in comparison with the control group and a significant increase in the time spent for the negative geotaxis performance in comparison with the control group, and a significant decrease in the head pocking, swimming scores in comparison with the control group, and increase in urination and defecation in comparison with the control group (Table 6).

\section{Discussion}

The oral $\mathrm{LD}_{50}$ of chlorpyrifos in mice was $193.05 \mathrm{mg} / \mathrm{kg}$ B.Wt, in the previous study the $\mathrm{LD}_{50}$ of chlorpyrifos in mice was $436.05 \mathrm{mg} / \mathrm{kg}$ body weight (31) this attributed to the differences in the manufacturing processes, preparations composition, variation of origin, as well as the solvents, the intermediate vehicles, the emulsifiers which added to be solved in water and the concentration of the active ingredient in the formula as well as season and laboratory temperature (32), It is worth to mention that chlorpyrifos from moderately toxic organophosphorus compounds their $\mathrm{LD}_{50}$ ranging between $50-500 \mathrm{mg} / \mathrm{kg}$, chlorpyrifos moderately toxic to mice and rats as well as sheep, guinea pigs $(3,5)$, but it is highly toxic in birds and poultry (7), non-vertebral aquatic organisms and fish (33), rabbits were resistant to chlorpyrifos toxicity due to their own levels of paraoxygenase enzyme that responsible for the analysis of chlorpyrifos Oxon (metabolic product of chlorpyrifos).

Chlorpyrifos and chlorpyrifos Oxon increase the production of the chlorpyrifos Oxon from the metabolism of chlorpyrifos in the liver metabolic pathways by CYP450 and lead to the increase in acetylcholinesterase inhibition percentage, poisoning signs and toxic effects will be more harmful (34).

Table 5: Neurobehavioral effects of $20 \%$ of $\mathrm{LD}_{50}$ of chlorpyrifos $38.6 \mathrm{mg} / \mathrm{kg}$ and deltamethrin $3.14 \mathrm{mg} / \mathrm{kg}$ PO in mice

\begin{tabular}{cccc}
\hline Variables & \multicolumn{3}{c}{ Treatment } \\
\cline { 2 - 4 } & Control group Distilled water & Chlorpyrifos & Deltamethrin \\
\hline Squares crossed / 3 min & $70 \pm 4.75$ & $26 \pm 4.6^{*}$ & $29.8 \pm 2.61^{*}$ \\
Rearing / 3 min & $18.76 \pm 1.78$ & $9.9 \pm 0.6^{*}$ & $9.6 \pm 1.0^{*}$ \\
Negative geotaxis (seconds) & $4.5 \pm 0.37$ & $12 \pm 1.01^{*}$ & $10.8 \pm 1.06^{*}$ \\
Head pocking 3 / min & $25.1 \pm 1.38$ & $6 \pm 0.9^{*}$ & $9 \pm 0.85^{*}$ \\
Fecal boluses / 3 min & $0.33 \pm 0.16$ & $1.5 \pm 0.22^{*}$ & $1.1 \pm 0.31^{*}$ \\
Urination pools / 3 min & $0.11 \pm 0.11$ & $0.8 \pm 0.13^{*}$ & $0.6 \pm 0.16^{*}$ \\
Swimming scores & $4 \pm 0$ & $3.2 \pm 0.13^{*}$ & $3.2 \pm 0.13^{*}$ \\
\hline
\end{tabular}

Values are (mean \pm SE) for 10 mice /group, * The value significantly different from the control group at $\mathrm{P}<0.05$. 
Table 6: Neurobehavioral effects of $10 \%$ of $\mathrm{LD}_{50}$ of Chlorpyrifos $19.3 \mathrm{mg} / \mathrm{kg}$ and Deltamethrin $1.57 \mathrm{mg} / \mathrm{kg}$ PO in mice

\begin{tabular}{lccc}
\hline \multirow{2}{*}{ Variables } & & Treatment & \\
\cline { 2 - 4 } Squares crossed / 3 min & Control group Distilled water & Chlorpyrifos & Deltamethrin \\
Rearing / 3 min & $69.4 \pm 4.1$ & $53.1 \pm 3.17^{*}$ & $58.5 \pm 3.54^{*}$ \\
Negative geotaxis (seconds) & $20.2 \pm 0.64$ & $12.2 \pm 1.17^{*}$ & $14.1 \pm 1.36^{*}$ \\
Head pocking 3 / min & $3.9 \pm 0.27$ & $9.9 \pm 0.5^{* \mathrm{a}}$ & $8.9 \pm 0.7^{*}$ \\
Fecal boluses / 3 min & $29.1 \pm 1.4$ & $14.2 \pm 1.39^{* \mathrm{a}}$ & $18.8 \pm 1.28^{*}$ \\
Urination pools / 3 min & $0.4 \pm 0.16$ & $1.2 \pm 0.13^{*}$ & $0.7 \pm 0.13$ \\
Swimming scores & $0.2 \pm 0.13$ & $0.6 \pm 0.16^{*}$ & $0.13 \pm 0.15$ \\
\hline
\end{tabular}

Values are mean \pm SE for 10 mice /group, * The value significantly different from the control group at $\mathrm{P}<0.05,{ }^{a}$ the value significantly different from deltamethrin treatment at $\mathrm{P}<0.05$.

The oral $\mathrm{LD}_{50}$ of deltamethrin in mice was $15.71 \mathrm{mg} / \mathrm{kg}$ B.Wt, it is known that deltamethrin $\mathrm{LD}_{50}$ ranged between $19-34 \mathrm{mg} / \mathrm{kg}$ body weight in deltamethrin preparations that contain vegetable oil or polyethylene glycol as a vehicle (35), the additives in deltamethrin preparations affects the $\mathrm{LD}_{50}$ value by affecting the absorption rate and lipophilic one will rapidly be absorbed (3).

Deltamethrin metabolized in liver through the breakdown of the ester bond, the only pathway for deltamethrin metabolism in the body, deltamethrin has the toxic effects without its own nontoxic metabolites $(23,36)$. The $80 \%$ of $\mathrm{LD}_{50}$ of chlorpyrifos and deltamethrin were selected and orally dosed equal to $155,12.56 \mathrm{mg} / \mathrm{kg} \mathrm{B}$.Wt., respectively, to observe and record the toxic signs that induced in these doses.

The mechanism of toxic action of chlorpyrifos after exposure and systemically absorbed was the inhibition of AchE in the neural tissue causing accumulation of Ach in the synaptic cleft so there is stimulation in the muscarinic and nicotinic receptors $(13,37)$ chlorpyrifos oral administration with $155 \mathrm{mg} / \mathrm{kg}$ B.Wt., which led to the appearance of poisoning signs that begin with muscarinic signs that manifested by dyspnea, salivation, lacrimation, defecation and urination, followed by the nicotinic signs and CNS effects that manifested by piloerection, straub tail, tremors followed by convulsions, also writhing reflex appeared in some treated mice and the signs ended with death due to the respiratory failure, these are the ideal signs of organophosphorus compounds (38).

Deltamethrin oral administration with $12.56 \mathrm{mg} / \mathrm{kg}$ B.Wt., led to the appearance of specific poisoning signs of type II synthetic pyrethroids which manifested by (choreoathetosis with salivation syndrome) (22) signs begins with chewing, salivation, pawing, piloerection, straub tail, tremors, rolling convulsions (specific signs of deltamethrin poisoning in rodents), eventually death because of respiratory failure (23), poisoning signs which appeared linked to the mechanisms of deltamethrin toxic action principally on the modulation of sodium channels gaits which present in the cellular membrane of the neuron which prolong the inhibition of sodium channels gaits and continuous sodium ions flow so it prolonged depolarization and resulting in the continuous stimulation and hyper activation of the nerve cells (20) also deltamethrin affects chloride ion channels as anti GABA receptors which prevents chloride ions flows (39), so this explains the occurrence of tremors, as well as deltamethrin affects $\mathrm{Ca}$ $\mathrm{Mg}$ ATPase resulting in the increase of intracellular calcium level which led to increase the stimulation of neurotransmitters release like Ach (22).

Doubling of the toxic doses will lead to increase the severity of the toxic signs and increase in their incidence and harm, as well as will increase in the death percentage $(40,41)$, this observed when we give double doses of chlorpyrifos $310 \mathrm{mg} / \mathrm{kg} \mathrm{B.Wt}$, and deltamethrin $24 \mathrm{mg} / \mathrm{kg}$ B.Wt., Which led to increase in the tremors, convulsions and death percentages, this differences in the toxic effects for insecticides depending on the differences in the toxicokinetic, toxicodynamic that responsible for the differences in the extent of toxicity $(42,43)$. Many studies depend on the neurobehavioral tests, which reveal the hidden negative effects that do not appear clearly when exposed to sub acute and chronic exposure of many insecticides that they do not appear overt poisoning signs and reflect their toxic effects on the nervous and muscular systems and their balance together (44).

In the current study many behavioral tests have been measured that reveal different types of behavioral functions such as open-field activity test which lowers the motor activity due to inhibition in the central nervous system (25), and negative geotaxis test, which increases the duration of negative geotaxis performance due to the defect in the vestibular function (26), and head pocking test that reveals the negative effects on the brain and it's cognitive function (27), In addition to the swimming test that decreases due to the defect in the coordination between the central nervous system and the muscular system and defects of the muscular system that response to the nervous system stimulation (28). 
The results of this study in mice that treated with chlorpyrifos and deltamethrin at low toxic doses are significant deceased in open-field activity (squares crossed and rearing), head pocking, swimming scores and significant increase in the duration of negative geotaxis performance in comparison with the control group, These behavioral changes are identical in the cases of organophosphorus compounds and pyrethroids poisoning in subacute and chronic exposure (45-47).

The neurobehavioral effects of the organophosphorus compounds at low toxic doses do not principally depend on the AchE inhibition, but depend on the effects of other neurotransmitters like dopamine, serotonin and GABA $(48,49,50)$, as well as neurobehavioral effects of pyrethroids which appears due to weakening of the neuromuscular response in low toxic doses $(47,51)$.

\section{Conclusion}

In conclusion, the acute toxic manifestations and severity of toxicity in chlorpyrifos and deltamethrin are similar to the signs of toxicosis and neurobehavioral effects that found with chicks $(46,52)$ and other animals when exposed to different toxicants with different mechanism of action.

\section{Acknowledgement}

This study was supported by the college of Veterinary Medicine, University of Mosul, Mosul, Iraq.

\section{References}

1. Sharma A, Mishra M, Shukla AK, Kumar R, Abdin MZ, Chowdhuri DK. Organochlorine pesticide, endosulfan induced cellular and organismal response in Drosophila melanogaster. J hazard Mater. 2012; 221:275-287. doi.org/10.1016/j.jhazmat.2012.04.045.

2. El-Shenawy NS. Effects of insecticides fenitrothion, endosulfan and abamectin on antioxidant parameters of isolated rat hepatocytes. ToxicolVitr.2010;24(4):1148-1157. doi.org/10.1016/j.tiv.2010.03.001.

3. Bendis RJ, Relyea RA. If you see one, have you seen them all?: Community-wide effects of insecticide cross-resistance in zooplankton populations near and far from agriculture. Environmental Pollution. 2016 Aug 1;215:234-46. doi.org/10.1016/j.envpol. 2016.05.020

4. Watts M. Chlorpyrifos as a possible global POP. Oakland: Academic Press; 2012. 23-33 p.

5. Pope C, Karanth S, Liu J. Pharmacology and toxicology of cholinesterase inhibitors: uses and misuses of a common mechanism of action. Environmental toxicology and pharmacology. 2005 May 1;19(3):433-46. doi.org/10.1016/j.etap.2004.12.048.

6. Karanth, S., and C. Pope. "Carboxylesterase and A-esterase activities during maturation and aging: relationship to the toxicity of chlorpyrifos and parathion in rats." Toxicological Sciences 2000, (2): 282-289.doi.org/10.1093/toxsci/58.2.282.

7. Shenouda, Josephine, Paula Green, and Lester Sultatos. "An evaluation of the inhibition of human butyrylcholinesterase and acetylcholinesterase by the organophosphate chlorpyrifos oxon."
Toxicology and applied pharmacology 2009, (2): 135-142. doi.org/10.1016/j.taap.2009.08.014.

8. Worek F, Koller M, Thiermann H, Szinicz L. Diagnostic aspects of organophosphate poisoning. Toxico. 2005; 214(3):182-189. doi.org/10.1016/j.tox.2005.06.012.

9. Roberts DM, Aaron CK. Management of acute organophosphorus $\begin{array}{lll}\text { pesticide poisoning. } & \text { BMJ. 2007;334(7):629-634. }\end{array}$ doi.org/10.1136/bmj.39134.566979.BE.

10. Al-Zubaidy MH, Amin WM. Cholinesterase inhibition in chicks treated with manganese chloride. Iraqi Journal of Veterinary Sciences. 2019 Jan 28;32(2):37-42.doi. 10.33899/ijvs.2019.153875

11. Ruark CD, Hack CE, Robinson PJ, Anderson PE, Gearhart JM. Quantitative structure-activity relationships for organophosphates binding to acetylcholinesterase. Archi Toxicol. 2013;87(2):281-289. doi.org/10.1007/s00204-012-0934-z.

12. Bajgar J. Organophosphates/nerve agent poisoning: mechanism of action, diagnosis, prophylaxis, and treatment. Adv Clin Chem. 2004 Jan 1;38(1):151-216.

13. Caloni F, Cortinovis C, Rivolta M, Davanzo F. Suspected poisoning of domestic animals by pesticides. Science of the total environment. 2016 Jan 1;539:331-6. doi.org/10.1016/j.scitotenv.2015.09.005

14. Lotti M. Cholinesterase inhibition: Complexities in interpretation. ClinicChemist.1995;41(12):1814-1818. doi.org/10.1093/clinchem/41.12.1814

15. Eddleston M, Buckley NA, Eyer P, Dawson AH. Management of acute organophosphorus pesticide poisoning. The Lancet. 2008;371(9):597-607. doi.org/10.1016/S0140-6736(07)61202-1.

16. Mangas I, Estevez J, Vilanova E, França TC. New insights on molecular interactions of organophosphorus pesticides with esterases. Toxicol. 2017;376:30-43. doi.org/10.1016/j.tox.2016.06.006.

17. Anadón A, Martínez MR, Martínez MA. Use and abuse of pyrethrins and synthetic pyrethroids in veterinary medicine. Vet $\mathrm{J}$. 2009;182(1):7-20. doi.org/10.1016/j.tvj1.2008.04.008.

18. Vais H, Williamson MS, Devonshire AL, Usherwood PN. The molecular interactions of pyrethroid insecticides with insect and mammalian sodium channels. Pest Manag Sci. 2001;57(10):877-888. doi.org/10.1002/ps.392.

19. Kaneko H. Pyrethroid chemistry and metabolism. In Hayes' Handbook of Pesticide Toxicology 2010 Jan 1 (pp. 1635-1663). Academic Press. doi.org/10.1016/B978-0-12-374367-1.00076-8

20. Tan J, Liu Z, Wang R, Huang ZY, Chen AC, Gurevitz M, Dong K. Identification of amino acid residues in the insect sodium channel critical for pyrethroid binding. Mol Pharmacol. 2005;67(2):513-522. doi: $10.1124 / \mathrm{mol} .104 .006205$

21. Davies TG, Field LM, Usherwood PN, Williamson MS. DDT, pyrethrins, pyrethroids and insect sodium channels. IUBMB Life. 2007;59(3):151-162. doi: 10.1080/15216540701352042.2

22. Bradberry SM, Cage SA, Proudfoot AT, Vale JA. Poisoning due to pyrethroids. Toxicol Rev. 2005;24(2):93-106.

23. Woodward KN. Veterinary pesticides. Mammalian Toxicology of Insecticides. 2012 Jan 19(12):348.

24. Dixon WJ. Efficient analysis of experimental observations. Ann Rev Pharmacol Toxicol. 1980;20:441-462.

25. Molinengo L, Fundarò A, Orsetti M. The effect of chronic atropine administration on mouse motility and on Ach levels in the central nervous system. Pharmacol Biochem Behav. 1989;32(4):1075-1077. doi: 10.1016/0091-3057(89)90085-3

26. Mohammad FK, St VO. Behavioral and developmental effects in rats following in utero exposure to 2, 4-D/2, 4, 5-t mixture. Neurobehav Toxicol Teratol.1986;8(5):551-560.

27. Soni K, Parle M. Anxiolytic Effects of Trachyspermum ammi Seeds in Mice. Journal of Pharmaceutical Sciences and Pharmacology. 2017 Mar 1;3(1):71-4. doi.org/10.1166/jpsp.2017.1077.

28. Vorhees CV, Brunner RL, Butcher RE. Psychotropic drugs as behavioral teratogens. Sci. 1979;205(4412):1220-1225. doi: $10.1126 /$ Science. 472738 . 
29. Katz M. Study design and statistical analysis: A practical guide for clinicians. Cambridge University Press; 2006.66-119.

30. Runyon RP. Nonparametric statistics: A contemporary approach. New York: Addison Wesley Publishing Company; 1977. 42-87 p.

31. AL-Baggou, B.Kh. Neurobehavioral and biochemical changes induced by interaction between cadmium and some insecticides in mice. phD thesis, Mosul university, Mosul, Iraq.

32. Świergosz R, Molenda P, Halota A. Effects of chemical and thermal stress on acetylcholinesterase activity in the brain of the bank vole Myodes glareolus. Ecotoxicol Environ Safe. 2014;106:204-212. doi: 10.1016/j.ecoenv.2014.04.021

33. Kamrin MA. Pesticide profiles: Toxicity, environmental impact, and fate. CRC press; 1997:147-152. doi.org/10.1201/9780367

34. Cole TB, Fisher JC, Burbacher TM, Costa LG, Furlong CE. Neurobehavioral assessment of mice following repeated postnatal exposure to chlorpyrifos oxon. Neurotoxicol Teratol. 2012;34(3):311322. doi.org/10.1016/j.ntt.2012.02.003.

35. Zhang ZW, Sun JX, Chen SY, Wu YQ, He FS. Levels of exposure and biological monitoring of pyrethroids in spraymen. Occup Environ Med. 1991;48(2):82-86. doi: 10.1136/oem.48.2.82.

36. Croucher L, Jewess P, Roberts MC. Metabolic pathways of agrochemicals: part 2: insecticides and fungicides. Royal Society of Chemistry; 2007 Oct 31.

37. Lotti M. Clinical toxicology of anticholinesterase agents in humans. Toxicol. 2010:1543-1589. doi: 10.1016/B978-0-12-374367-1.00072-0

38. Caloni F, Cortinovis C, Rivolta M, Davanzo F. Suspected poisoning of domestic animals by pesticides. Sci Total Environ. 2016;539:331. doi: 10.1016/j.scitotenv.2015.09.005

39. Burr SA, Ray DE. Structure-activity and interaction effects of 14 different pyrethroids on voltage-gated chloride ion channels. Toxicol Sci. 2004;77(2):341-346. doi: 10.1093/toxsci/kfh027

40. Shafer TJ, Meyer DA, Crofton KM. Developmental neurotoxicity of pyrethroid insecticides: Critical review and future research needs. Environ Heal Perspect. 2004;113(2):123-136. doi: 10.1289/ehp.7254

41. Wolansky MJ, Gennings C, DeVito MJ, Crofton KM. Evidence for dose-additive effects of pyrethroids on motor activity in rats. Environ Heal Perspect. 2009;117(10):1563-1570. doi: 10.1289/ehp.0900667

42. Timchalk C, Poet TS, Kousba AA. Age-dependent pharmacokinetic and pharmacodynamic response in preweanling rats following oral exposure to the organophosphorus insecticide chlorpyrifos. Toxicol. 2006;220(1):13-25. doi: 10.1016/j.tox.2005.11.011
43. Pope C. The influence of age on pesticide toxicity. Toxicol. 2010;819835. doi: 10.1016/B978-0-12-374367-1.00032-X

44. Dam K, Seidler FJ, Slotkin TA. Chlorpyrifos exposure during a critical neonatal period elicits gender-selective deficits in the development of coordination skills and locomotor activity. Develop Brain Res. 2000;121(2):179-87. doi: 10.1016/S0165-3806(00)00044-4

45. Luty S, Latuszynska J, Obuchowska-Przebirowska D, Tokarska M, Haratym-Maj A. Subacute toxicity of orally applied alphacypermethrin in Swiss mice. Ann Agri Environ Med. 2000;7(1):33-41.

46. Al-Badrany YM, Mohammad FK. Effects of acute and repeated oral exposure to the organophosphate insecticide chlorpyrifos on openfield activity in chicks. Toxicol letters. 2007;174(1-3):110-116. doi: 10.1016/j.toxlet.2007.09.001

47. Yavuz O, Kayir H, Yilmaz I, Ulusoy G, Cakir G, Uzbay IT. Subacute neurobehavioral effects of dermally-applied alpha cypermethrin in rats. Rev Med Vet. 2009;160:184-191.

48. Aldridge, Justin E., Edward D. Levin, Frederic J. Seidler, and Theodore A. Slotkin. "Developmental exposure of rats tochlorpyrifos leads to behavioral alterations in adulthood, involving serotonergic mechanisms and resembling animal models of depression." Environmental health perspectives 113, no. 5 (2005): 527-531. doi.org/10.1289/ehp.7867.

49. Aldridge JE, Seidler FJ, Slotkin TA. Developmental exposure to chlorpyrifos elicits sex-selective alterations of serotonergic synaptic function in adulthood: Critical periods and regional selectivity for effects on the serotonin transporter, receptor subtypes, and cell signaling. Enviro Heal Perspect. 2004;112(2):148-155. doi: 10.1289/ehp.6713

50. Aldridge JE, Levin ED, Seidler FJ, Slotkin TA. Developmental exposure of rats to chlorpyrifos leads to behavioral alterations in adulthood, involving serotonergic mechanisms and resembling animal models of depression. Environ Heal Perspect. 2005;113(5):527-531. doi: 10.1289/ehp.7867

51. Wolansky MJ, Harrill JA. Neurobehavioral toxicology of pyrethroid insecticides in adult animals: A critical review. Neurotoxicol Teratol. 2008;30(2):55-78. doi: 10.1016/j.ntt.2007.10.005

52. Al- Baggou BK. Subacute cholinesterase inhibition and behavioral effects of chlorpyrifos experimentally supplied via drinking water in chicks. Hum Vet Med. 2014;2(6):70-75. 